\title{
IRRIGATION WITH SALINE WATER ON PINEAPPLE GROWN IN THE SEMI-ARID OF BAHIA STATE
}

\author{
IRRIGAÇÃO COM ÁGUA SALINA NA CULTURA DO ABACAXIZEIRO NO \\ SEMIÁRIDO BAIANO
}

\author{
Cleiton Fernando Barbosa BRITO ${ }^{1 *}$; Varley Andrade FONSECA ${ }^{1}$; \\ Marcelo Rocha dos SANTOS ${ }^{2}$; Alessandro de Magalhães ARANTES ${ }^{2}$; \\ Sergio Luiz Rodriguez DONATO ${ }^{2}$
}

1. Doutorando do Programa de Pós-Graduação em Produção Vegetal no Semiárido, Universidade Estadual de Montes ClarosUNIMONTES, Janaúba, MG, Brasil. cleiton.ibce@hotmail.com; 2. Professor do Instituto Federal de Educação, Ciência e Tecnologia Baiano, Guanambi, BA, Brasil.

\begin{abstract}
We aimed to evaluate the effects of different irrigation depths with saline water on growth, yield, water-use efficiency, and fruit quality of 'Pérola' pineapple plant grown in the semi-arid of Bahia state. The experiment was carried out in a randomized block design with five treatments which represented the irrigation depths: $100 \%$ of crop evapotranspiration (ETc) with irrigation water of $0.75 \mathrm{dS} \mathrm{m}^{-1}$ in electrical conductivity $\left(\mathrm{EC}_{\mathrm{iw}}\right)$; and $50,75,100$, and $125 \%$ of $\mathrm{ETc}$ with water of $3.6 \mathrm{dS} \mathrm{m}^{-1}$ in $\mathrm{EC}_{\mathrm{iw}}$. Pineapples were grown under field conditions watered by drip irrigation in which pressure compensating emitters had $8 \mathrm{~L}$ $\mathrm{h}^{-1}$ flow rate. We observed that the irrigation depth $100 \%$ of ETc with water of 0.75 and $3.6 \mathrm{dS} \mathrm{m}^{-1}$ in $\mathrm{EC}_{\mathrm{iw}}$ provides higher pineapple yields under the semi-arid conditions of this study, and the chemical quality of the fruits are up to commercial standards, except when applying $125 \%$ of ETc with water of $3.6 \mathrm{dS} \mathrm{m}^{-1}$ in $\mathrm{EC}_{\mathrm{iw}}$.
\end{abstract}

KEYWORDS: Ananas comosus. Salinity. CAM plants. Irrigation management.

\section{INTRODUCTION}

The pineapple plant (Annas comosus L. Merril) is physiologically characterized by employing a carbon fixation pathway called Crassulacean Acid Metabolism (CAM) (ARAGON et al., 2012; ZHANG et al., 2014; COUTO et al., 2016), which reduces the loss of water due to the daytime stomatal closure and nocturnal stomatal opening with $\mathrm{CO}_{2}$ fixation, and better water-use efficiency under dry conditions (CARR, 2012).

By using these characteristics and an adequate irrigation management, the pineapple can become an alternative crop in semi-arid regions (AZEVEDO et al., 2007; MOTA et al., 2016), as it has potential to maintain its yield under hot and dry climates (BORLAND et et al., 2014) and, therefore, it is a new addition to the irrigated crops grown in the semi-arid of Bahia state.

Studies on pineapple grown in semi-arid regions, under irrigated conditions, were conducted (FRANCO et al., 2014; PEGORARO et al., 2014; MAIA et al., 2016); however, there is a dearth of information with regard to phytotechnical characteristics and quality of pineapple fruits irrigated with saline water inasmuch as the main studies on this subject were conducted by using pots under salinity-induced conditions (IBRAHIM, 2013), growth medium (ELHAG; ELZAIN, 2012), and a hydroponic system (MELO et al., 2017); hence, field studies with pineapples irrigated with saline water are necessary.

When using saline water as irrigation water, an irrigation depth that ensures the leaching of a portion of the salts in the soil is fundamental to reduce the salinity near the rootzone. For this reason, defining an ideal volume of water for the purpose of salt leaching, which would provide the roots with an adequate environment for development, is needed (ARAGÜÉSA et al., 2014; GUIMARÃES et al., 2016). This also justifies the conduction of research on application of different irrigation depths with saline water, with the aim of obtaining local recommendations that take into account the crop, the soil, and the quality and quantity of the irrigation water, so as to not negatively affect the soil-plant system. Therefore, we aimed to evaluate the effects of different irrigation depths with saline water on growth, yield, and fruit quality of 'Pérola' pineapple plants grown in the semi-arid of Bahia state.

\section{MATERIAL AND METHODS}

The study was carried out between April 2015 and October 2016, in an experimental area at the Federal Institute of Education, Science, and Technology of Bahia (IF Baiano), campus 
Guanambi. It is located at Ceraíma District, municipality of Guanambi, southeastern Bahia, Brazil, whose latitude, longitude, and altitude are $14^{\circ} 46^{\prime} \mathrm{S}, 42^{\circ} 46^{\prime} \mathrm{W}$, and $545 \mathrm{~m}$, respectively. Climate, semi-arid Aw type, by the Köppen Classification (ALVARES et al., 2013) and the average annual rainfall is $680 \mathrm{~mm}$, with a rainy season between November and March, and average temperature of $25.78^{\circ} \mathrm{C}$.
Maximum and minimum temperatures, rainfall, relative humidity, wind speed (gust), and reference evapotranspiration that were recorded during the conduction of the experiment are in Figure 1. It can be seen that the maximum temperatures are around $40{ }^{\circ} \mathrm{C}$; there were rains in November, December, and January; and wind is moderate to strong, with gusts of wind going up to $85 \mathrm{~km} \mathrm{~h}^{-1}$.

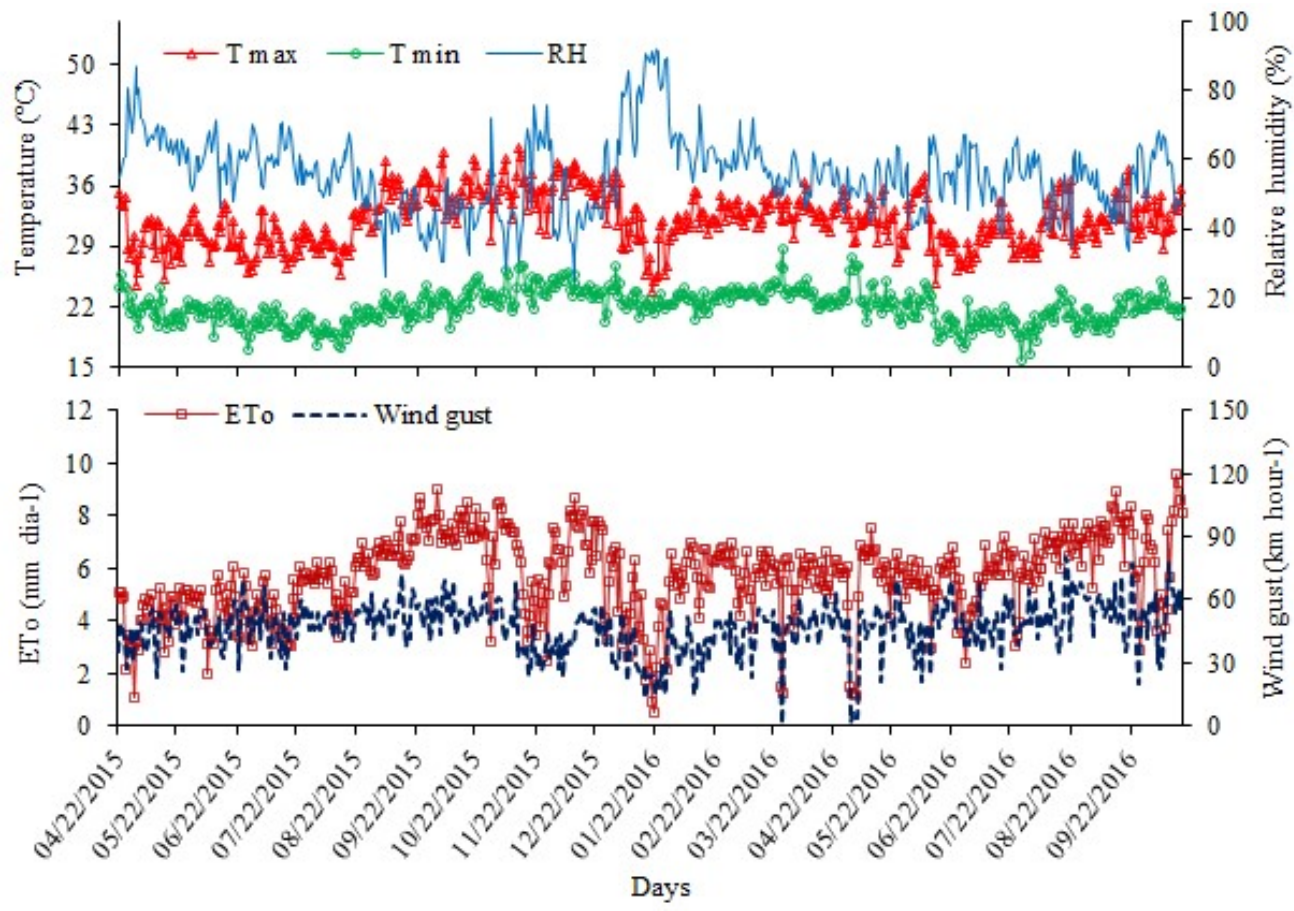

Figure 1. Maximum and minimum temperatures (Tmax and Tmin, respectively), relative humidity (RH), and gusts of wind, rainfall, and reference evapotranspiration (ETo) during the conduction of the experiment.

The pineapple plants were grown in a typical dystrophic yellow-red Latosol (Oxysol), weak A horizon, with terrain varying from flat to wavy and smooth. The chemical (TEDESCO et al., 1995) and textural (EMBRAPA, 1997) characteristics at the depth of 0 to $20 \mathrm{~cm}$, before the onset of the experiment, were: $\mathrm{pH}$ (in water) $=5.7$; $\mathrm{P}$ (Mehlich 3 extractant) $=23.5 \mathrm{mg} \mathrm{dm}^{-3} ; \mathrm{K}$ (Mehlich 3 extractant) $=108 \mathrm{mg} \mathrm{dm}^{-3} ; \mathrm{Na}=0.1$ $\mathrm{cmol}_{\mathrm{c}} \mathrm{dm}^{-3} ; \mathrm{Ca}=1.4 \mathrm{cmol}_{\mathrm{c}} \mathrm{dm}^{-3} ; \mathrm{Mg}=0.6 \mathrm{cmol}_{\mathrm{c}}$ $\mathrm{dm}^{-3} ; \mathrm{Al}=0.0 \mathrm{cmol}_{\mathrm{c}} \mathrm{dm}^{-3} ; \mathrm{H}+\mathrm{Al}=1.7 \mathrm{cmol}_{\mathrm{c}} \mathrm{dm}^{-3}$; Sum of bases $=2.4 \mathrm{cmol}_{\mathrm{c}} \mathrm{dm}^{-3}$; effective cation exchange capacity $(\mathrm{ECEC})=2.4 \mathrm{cmol}_{\mathrm{c}} \mathrm{dm}^{-3}$; cation exchange capacity $(\mathrm{CEC})=4.1 \mathrm{cmol}_{\mathrm{c}} \mathrm{dm}^{-3}$; base saturation $=58 \% ; \mathrm{B}=0.3 \mathrm{mg} \mathrm{dm}^{-3} ; \mathrm{Cu}=0.4 \mathrm{mg}$ $\mathrm{dm}^{-3} ; \mathrm{Fe}=16.0 \mathrm{mg} \mathrm{dm}^{-3} ; \mathrm{Mn}=32.5 \mathrm{mg} \mathrm{dm}^{-3} ; \mathrm{Zn}=$ $2.1 \mathrm{mg} \mathrm{dm}^{-3}$; electrical conductivity $=0.7 \mathrm{dS} \mathrm{m}^{-1}$; sandy $=68 \mathrm{dag} \mathrm{kg}^{-1} ;$ silt $=11 \mathrm{dag} \mathrm{kg}^{-1}$; and clay $=21$ dag $\mathrm{kg}^{-1}$.
The planting of the 'Pérola' pineapple seedlings (suckers) was performed in April 2015, in simple rows, spaced out $0.25 \mathrm{~m}$ apart between plants within the row and $1.2 \mathrm{~m}$ between rows, which added up to a population of 33,300 plants $\mathrm{ha}^{-1}$. The soil correction, fertilization at planting, and top dressing were done in accordance with the soil test from the experimental area, according to Reinhardt et al. (2000). Were applied 320, 90 and $240 \mathrm{~kg} \mathrm{ha}^{-1}$ of $\mathrm{N}, \mathrm{P}_{2} \mathrm{O}_{5}$ and $\mathrm{K}_{2} \mathrm{O}$, respectively. A month after planting, urea, zinc sulfate, and potassium chloride were applied to the plants as foliar fertilizers. Afterwards, every two months, urea ( $\left.5 \mathrm{~g} \mathrm{plant}^{-1}\right)$ and $\mathrm{KCl}\left(2.5 \mathrm{~g} \mathrm{plant}^{-1}\right)$ were applied to the plants by hand. During the experiment, standard crop and phytosanitary practices were performed in which a low incidence of pests and diseases was observed.

We used drip irrigation in which the pressure compensating emitters had a nominal flow rate of $8 \mathrm{~L} \mathrm{~h}^{-1}$. The spacing between emitters was 
Irrigation with saline...

$0.75 \mathrm{~m}$, which created a continuous wet strip alongside the plant rows. At 180 and 360 days after planting, water application efficiency tests were performed with values of 68 and $60 \%$, respectively. $\mathrm{Up}$ to the fourth month after planting, all the experimental plots received the same amount of water in a daily basis in order to even the water content in the soil and to favor the initial growth of the seedlings and the establishment of the crop. From then on, we started to apply different irrigation depths. The irrigation run time (equation 1) was calculated of according Santos et al. (2015). The crop evapotranspiration (ETc) was obtained by the product of the reference evapotranspiration (ETo), which was daily determined with the data from a weather station installed at $200 \mathrm{~m}$ from the experimental area by the Penman-Monteith method, and the crop coefficient (Kc). The Kc was of 0.8 at the initial stages of crop establishment, and 1.0 at the vegetative stage and after the flower induction (reproductive stage), according to Santana et al. (2013).

$$
\mathrm{IT}=\frac{\mathrm{ETc} \times \mathrm{Kl} \times \mathrm{S}_{1} \times \mathrm{S}_{2}}{\mathrm{q} \times \mathrm{Ef}}
$$

which means,

$\mathrm{IT}=$ Irrigation run time $(\mathrm{h})$;

ETc $=$ Crop evapotranspiration $\left(\mathrm{mm} \mathrm{day}^{-1}\right)$;
BRITO, C. F. B. et al.

$\mathrm{S} 1=$ Spacing between plants within the row $(\mathrm{m})$;

$\mathrm{S} 2$ = Spacing between row of plants (m);

$\mathrm{K} 1=$ Localized coefficient (no dimension)

$\mathrm{q}=$ Emitter discharge $\left(\mathrm{L} \mathrm{h}^{-1}\right)$

$\mathrm{Ef}=$ Application efficiency (decimal), determined during the experiment

The localized coefficient (K1) that was used to calculate the irrigation time equaled to 1 because of the overlapping wet strips.

The experiment was carried out in randomized block design with five treatments (irrigation depths): $100 \%$ of ETc with irrigation water of $0.75 \mathrm{dS} \mathrm{m}^{-1}$ in electrical conductivity $\left(\mathrm{EC}_{\mathrm{iw}}\right)$; and $50,75,100$, and $125 \%$ of ETc with water

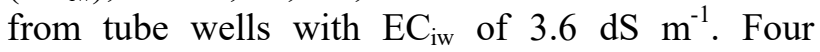
replicates were used. The experimental unit consisted of four 8-m-long rows of plants in which the measurement plants were located in 4-meterlong central portions of the two central rows, adding up to 26 measurement plants in each plot.

The gross irrigation depth applied over the crop cycle was $3,250.11 \mathrm{~mm}$ for the treatment $100 \%$ of ETc with water of $0.75 \mathrm{dS} \mathrm{m}^{-1}$ in $\mathrm{EC}_{\mathrm{iw}} ; 1,742.30$; 2,535.25; 3,288.26; and 4,314.99 $\mathrm{mm}$ for 50, 75, 100 , and $125 \%$ of ETc, respectively, with water of $3.6 \mathrm{dS} \mathrm{m}^{-1}$ in $\mathrm{EC}_{\mathrm{iw}}$. The total rainfall over the course of the experiment was $726.63 \mathrm{~mm}$ (Figure 2).

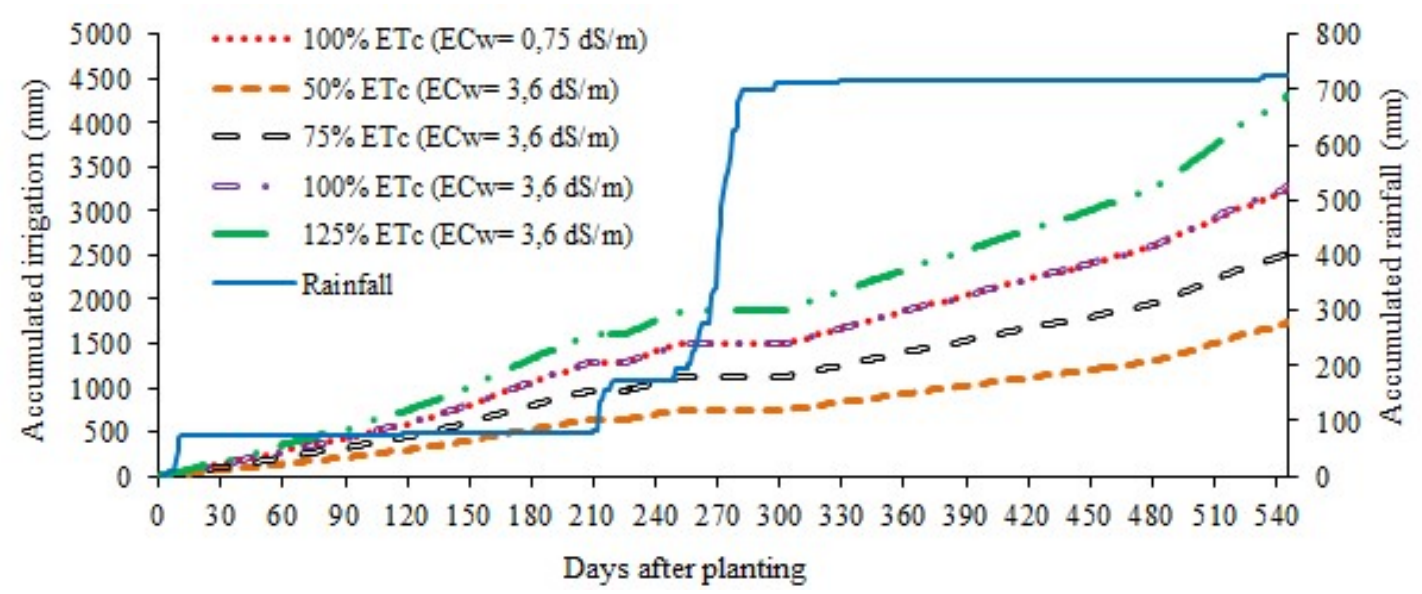

Figure 2. Accumulate irrigation applied to different treatments and accumulated rainfall during the experimental period.

The water from tube well that was used in the trials with $50,75,100$, and $125 \%$ of ETc has a $\mathrm{pH}$ of 6.4 , electrical conductivity of $3.6 \mathrm{dS} \mathrm{m}^{-1}$, $11.90 \mathrm{meq} \mathrm{L}^{-1}$ of calcium, $9.54 \mathrm{meq} \mathrm{L}^{-1}$ of magnesium, $0.48 \mathrm{meq} \mathrm{L}^{-1}$ of bicarbonate, and 34.80 meq $\mathrm{L}^{-1}$ of chloride; which was classified as $\mathrm{C} 4 \mathrm{~S} 1$, in accordance with (RICHARDS, 1954).
The artificial flower induction of the pineapple plant was done on the $13^{\text {th }}$ month after planting, by applying ETHREL $240 \mathrm{~g} \mathrm{~L}^{-1}$ of Ethephon, synthetic growth regulator, which is a precursor of ethylene. Its application was done by using a 20-L hand-pumped backpack sprayer. We added $40 \mathrm{~mL}$ of ETHREL $+400 \mathrm{~g}$ of urea $(2 \%)$ in 
Irrigation with saline...

each $20 \mathrm{~L}$ container, and we applied $50 \mathrm{~mL}$ of this mix into the leaf rosette of the plant.

After the beginning of application of the treatments, we took readings every month of the following vegetative characteristics: plant height, from the soil surface to the very top of the plant with the aid of a measuring tape; shoot diameter, measured with the aid of a flexible plastic measuring tape; number of leaves, determined by counting the total number of leaves; length and width of the ' $D$ ' leaf, measured with the aid of a ruler, from the base of the leaf to its tip. Based on length and width, leaf area " $D$ " was determined (equation 2) and then the total leaf area of the plant (equation 3) according to Santos et al. (2018).

$$
\mathrm{DLA}=-214,727+(2,938 \times \mathrm{DLL})+(74,329 \times \mathrm{DLW})
$$

in which:

DLA = pineapple "D" leaf area $\left(\mathrm{cm}^{2}\right)$

DLL $=$ "D" leaf length $(\mathrm{cm})$

$\mathrm{DLW}=$ "D" leaf width $(\mathrm{cm})$.

$\mathrm{TLA}=214,727+(17,4297 \times$ DLA $)$

in which:

TLA $=$ total leaf area of the pineapple plants $\left(\mathrm{cm}^{2}\right)$

The harvest of pineapple fruits was performed 17 months after the planting and 5 months after the flower induction. After the harvest, the fresh mass of the crowned fruit was directly weighed with a precision scale. By using the mass and number of fruits picked from the measurement plants within the plot $\left(9.6 \mathrm{~m}^{2}\right)$, we estimated the yield $\left(\mathrm{kg} \mathrm{ha}^{-1}\right)$.

The characterization of the chemical quality of the pineapple fruits was done by assessing the total soluble solids (TSS), $\mathrm{pH}$, total titratable acidity (TTA), and the TSS/TTA ratio. In an agro-industrial laboratory at the IF Baiano campus Guanambi, we cut the pineapple open and removed a circular sample from it. Then, we mashed it up in a container to obtain the juice from which we used about a drop for the Reichert ${ }^{\circledR}$ digital refractometer readings, where the TSS contents were directly expressed as degree Brix ( ${ }^{\circ}$ Brix).

The determination of the potential of hydrogen $(\mathrm{pH})$ and TTA was done by weighing $10 \mathrm{~g}$ of pineapple pulp and then adding $50 \mathrm{ml}$ of deionized water to make some juice. For TTA, we collected $10 \mathrm{ml}$ of juice, in which we applied three drops of phenolphthalein (alcoholic solution). After
BRITO, C. F. B. et al.

that, we proceeded to titrate it with sodium hydroxide solution $0.1 \mathrm{~N}$ and the results were expressed as mg of citric acid/100 $\mathrm{g}$ of juice. As for the $\mathrm{pH}$ was directly measured with a digital $\mathrm{pH}$ meter.

The water-use efficiency (WUE) was calculated for every treatment by taking into account the relationship between yield and gross irrigation depth and the rain totals, according to Santos et al. $(2014 ; 2015)$.

The data of yield, growth, fruit quality, and WUE were subjected to analysis of variance and, when needed, the interactions were grouped in accordance with their significance. The means of the variables were compared with each other by the Tukey's test $(p<0.05)$ for the factor 'irrigation depth'. As for the factor 'days after planting (DAP)', regression was used. The corrections of the regression equations were made to fit the model to the studied phenomenon, were based on the significance level of the regression parameters by the $t$ test at $5 \%$ of significance level, and on the adjusted coefficient of determination $\left(\mathrm{R}^{2}\right)$.

\section{RESULTS AND DISCUSSION}

There was a significant interaction $(\mathrm{p}<0.05)$ only for the number of leaves of 'Pérola' pineapple plant for the studied factors (irrigation depth and days after planting - DAP) (Figure 3). Plant height (PT), shoot diameter (SD), length of 'D' leaf (LDL), width of ' $\mathrm{D}$ ' leaf (WDL), and leaf area (LA) in pineapple plants under different irrigation depths with saline water exhibited an isolate effect both for months (Figure 3 ) and irrigation depth (Table 1).

In regard to the number of leaves (NL), through the regression models (Figure 3), we verified a quadratic behavior with a maximum point occurring at approximately 280 DAP when irrigating with water of $3.6 \mathrm{dS} \mathrm{m}^{-1}$ in $\mathrm{EC}_{\mathrm{iw}}$. As for $100 \%$ of ETc with water of $0.75 \mathrm{dS} \mathrm{m}^{-1}$ in $\mathrm{EC}_{\mathrm{iw}}$, the maximum point occurs at 390 DAP. It is inferred that saline water, regardless of the amount, can prematurely reduce the number of leaves and, consequently, contribute to negative results in yield.

There was no effect of the irrigation depths on the number of leaves at 150,180,210,300, and 330 days after planting (Figure 3). Perhaps, the same number of leaves in the first three assessments reflects the effect of full irrigations in the first four months after planting. After the 210 DAP, plants, to which $125 \%$ of ETc was applied with water of 3.6 $\mathrm{dS} \mathrm{m}^{-1}$ in $\mathrm{EC}_{\mathrm{iw}}$, had the lowest number of leaves. This is probably because of the higher accumulation of salts in the soil due to the higher irrigation depth. 
At the assessments done at 300 and 330 DAP, there were no differences between the number of leaves in the irrigated treatments, which might be explained by the leaching of salts into the soil due to the rains that fell over the period between 210 and 280 DAP (Figure 2), which added up to $600 \mathrm{~mm}$. After this period, the irrigation with saline water, regardless of the depth, contributed to the reduction of the number of leaves, which can be explained by the stress caused by the salinity associated with the higher evapotranspiration demand (Figure 1) at the end of the vegetative stage of pineapple plants. This was when we observed symptoms of potassium
BRITO, C. F. B. et al.

deficiency $\left(\mathrm{K}^{+}\right)$on mature leaves, so these injured leaves were not counted as being active leaves.

Studies under conditions of induced salinity, which is accomplished by diluting seawater with the irrigation water, point out that the number of leaves of pineapple plants is inhibited by the increase in electrical conductivity (HAMED; ALI, 2007). This reduction is due to the accumulation of sodium $(\mathrm{Na})$ in the vacuoles, which ends up replacing mainly the $\mathrm{K}^{+}$(HANAFI et al., 2010); therefore, the outcomes of this study are consistent with those cited in the literature.

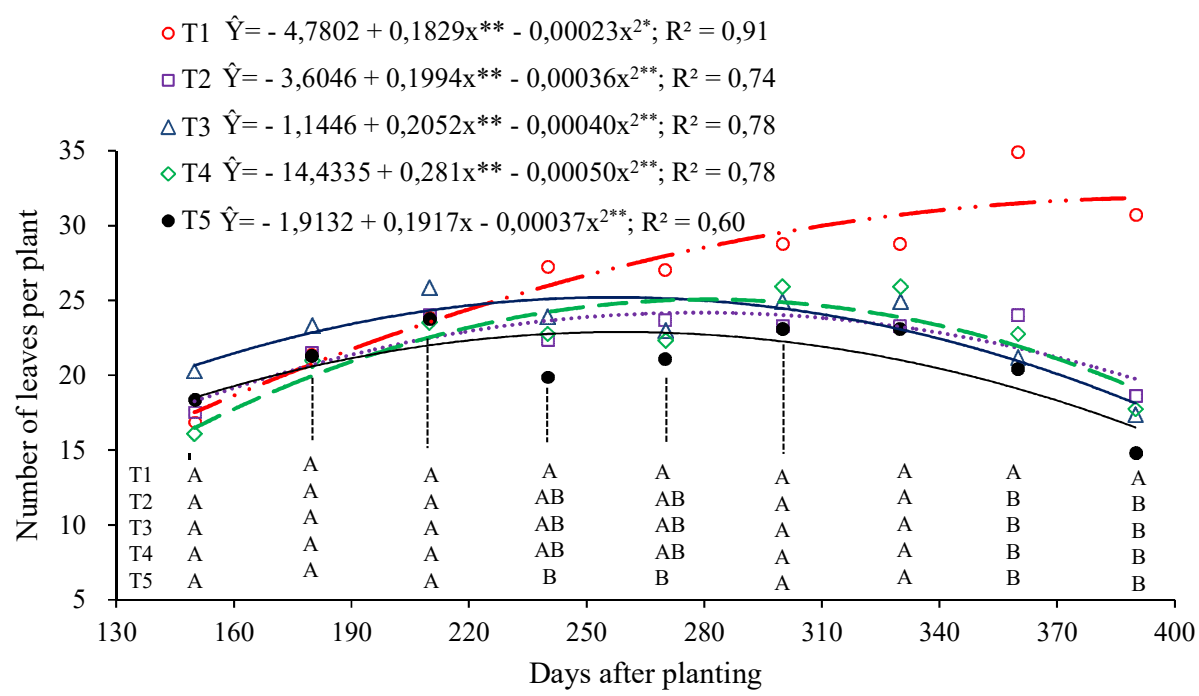

Figure 3. Number of leaves in 'Pérola' pineapple plants subjected to different irrigation depths with saline water over the months.

Same letters for irrigation depths on days after planting do not differ from each other by the Tukey's test at $5 \%$ of significance level. T1: $100 \% \operatorname{ETc}\left(\mathrm{EC}_{\mathrm{iw}}=0,75 \mathrm{dS} \mathrm{m}^{-1}\right), \mathrm{T} 2: 50 \% \mathrm{ETc}\left(\mathrm{EC}_{\mathrm{iw}}=3,6 \mathrm{dS} \mathrm{m} \mathrm{m}^{-1}\right), \mathrm{T} 3: 75 \% \mathrm{Etc}\left(\mathrm{EC}_{\mathrm{iw}}=3,6 \mathrm{dS} \mathrm{m}^{-1}\right), \mathrm{T} 4: 100 \% \mathrm{ETc}$ $\left(\mathrm{EC}_{\mathrm{iw}}=3,6 \mathrm{dSm}-1\right)$; T5: $125 \% \mathrm{ETc}\left(\mathrm{EC}_{\mathrm{iw}}=3,6 \mathrm{dS} \mathrm{m}^{-1}\right)$.

Plant height, width of ' $\mathrm{D}$ ' leaf, leaf area, and leaf area index of 'Pérola' pineapple plants as a function of days after plating (DAP) were adjusted to a cubic regression model (Figure 4). As for the values of shoot diameter and length of the ' $\mathrm{D}$ ' leaf, they were adjusted to a quadratic model.

These cubic adjustments are possibly due to the adverse environmental conditions during the conduction of the experiment in field as the plant behavior over time is linear (RODRIGUES et al., 2010; CARDOSO et al., 2013). Conversely, the quadratic variation was prominent, mainly for that of the length of ' $D$ ' leaf, which reached up to 68.76 $\mathrm{cm}$ at 374.3 days after planting; then, it gradually went down. This trend can be justified by the competitions of plants for sunlight and by the decrease in soil fertility, even though the soil had been properly fertilized (FRANCO et al., 2014). 

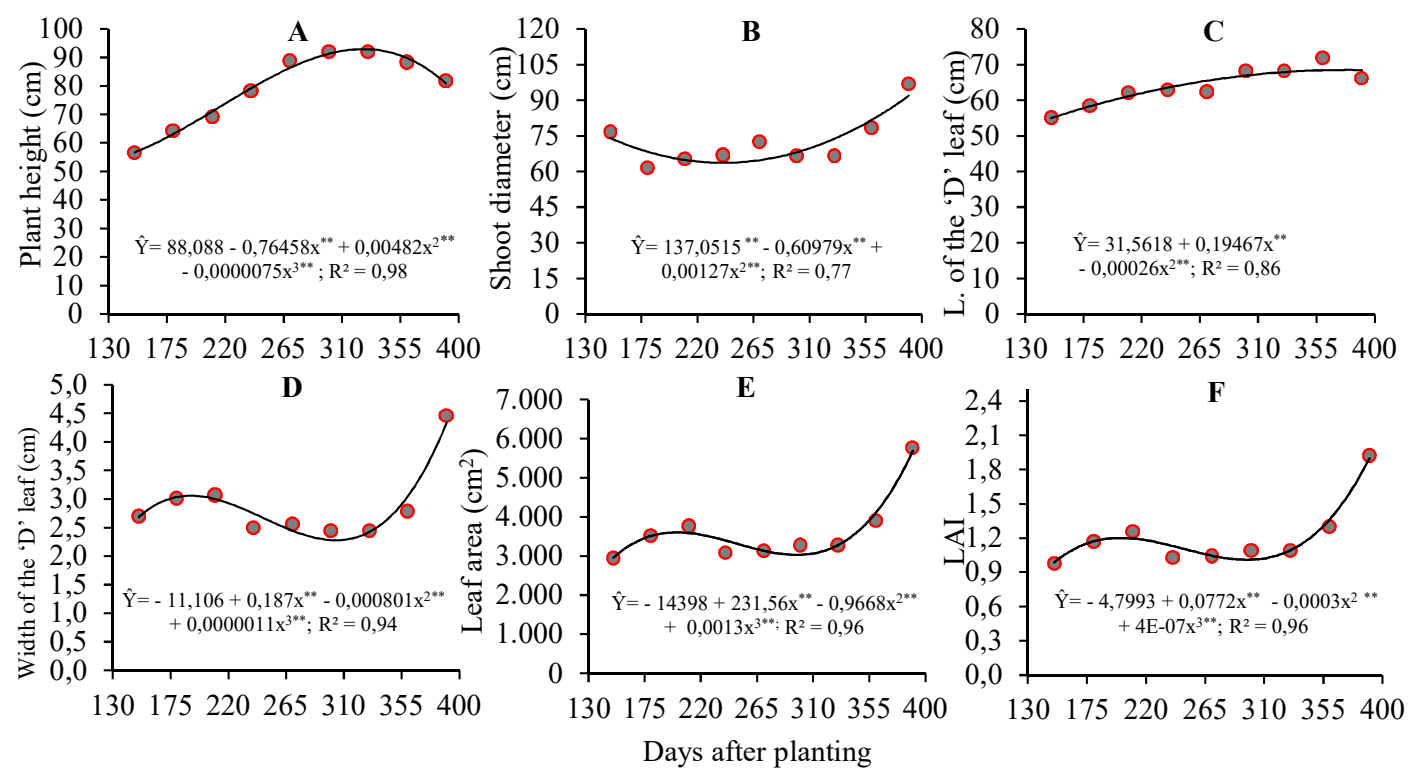

Figure 4. Plant height, shoot diameter, length of the ' $D$ ' leaf, width of the ' $D$ ' leaf, leaf area, and leaf area index (LAI) of 'Pérola' pineapple plants subjected to different irrigation depths with saline water over the months.

The lowest value of shoot diameter was observed in plants watered with $125 \%$ of ETc with water of $3.6 \mathrm{dS} \mathrm{m}^{-1}$ in $\mathrm{EC}_{\mathrm{iw}}$ (Table 1). The value of length of the ' $\mathrm{D}$ ' leaf in pineapples irrigated with $100 \%$ of ETc with water of $0.75 \mathrm{dS} \mathrm{m}^{-1}$ in $\mathrm{EC}_{\text {iw }}$ did not differ from those watered with $50 \%$ of ETc with water of $3.6 \mathrm{dS} \mathrm{m}^{-1}$ in $\mathrm{EC}_{\mathrm{iw}}$; however, it differed from the depths of $75 \%, 100 \%$, and $125 \%$ of ETc with water of $3.6 \mathrm{dS} \mathrm{m}^{-1}$ in $\mathrm{ECw}$. As for the width of the 'D' leaf, $100 \%$ of ETc with water of $0.75 \mathrm{dS} \mathrm{m}^{-1}$ in $\mathrm{EC}_{\mathrm{iw}}$ yielded the highest mean value $(3.23 \mathrm{~cm})$.

Given the above, it is evidenced that saline water was not a factor limiting crop growth with regard to plant height, length of the ' $\mathrm{D}$ ' leaf, and shoot diameter; nevertheless, saline water in association with irrigation depth did limit the plant growth when $125 \%$ of ETc was applied with saline water of $3.6 \mathrm{dS} \mathrm{m}^{-1}$ in $\mathrm{EC}_{\mathrm{iw}}$. Conversely, in commercial crop fields, where high yield is the primary goal, a mature plant should be $100 \mathrm{~cm}$ to
$120 \mathrm{~cm}$ high and $100 \mathrm{~cm}$ to $150 \mathrm{~cm}$ wide (REINHARDT et al., 2000). Over the pineapple's vegetative cycle, temperatures higher than what is considered to be optimal for the crop occurred in the experiment (22 to $32{ }^{\circ} \mathrm{C}$ ) (Figure 1), which can explain this poor growth rate, as the pineapple has its growth restricted in temperatures above $32{ }^{\circ} \mathrm{C}$ and below $22{ }^{\circ} \mathrm{C}$ (REINHARDT, 2000).

As well as the remaining vegetative variables, the total leaf area of pineapples exhibited the highest mean value of $4,339.05 \mathrm{~cm}^{2}$ when applying $100 \%$ of ETc with water of $0.75 \mathrm{dS} \mathrm{m}^{-1}$ in $\mathrm{EC}_{\mathrm{iw}}$ (Table 1). Nonetheless, as a result of the values of length and width of the ' $\mathrm{D}$ ' leaf, the leaf area of depths $75 \%, 100 \%$, and $125 \%$ of ETc with water of $3.6 \mathrm{dS} \mathrm{m}^{-1}$ in $\mathrm{EC}_{\mathrm{iw}}$ also exhibited lower results than those found in the literature in which we find values varying from 4,000 to $12,000 \mathrm{~cm}^{2}$ (MELO et al., 2006).

Table 1. Plant height (PT), shoot diameter (SD), length of the ' $D$ ' leaf (LDL), width of ' $D$ ' leaf (WDL), and total leaf area (TLA) in 'Pérola' pineapple plants subjected to different irrigation depths with saline water over the months.

\begin{tabular}{cccccc}
\hline Depths & PT $(\mathrm{cm})$ & SD $(\mathrm{cm})$ & LDL $(\mathrm{cm})$ & WDL $(\mathrm{cm})$ & TLA $\left(\mathrm{cm}^{2}\right)$ \\
\hline $100 \% \mathrm{ETc}^{2}\left(\mathrm{EC}_{\mathrm{iw}}=0,75 \mathrm{dSm}^{-1}\right)$ & $82.49 \mathrm{a}$ & $77.93 \mathrm{a}$ & $69.00 \mathrm{a}$ & $3.23 \mathrm{a}$ & $4339.05 \mathrm{a}$ \\
$50 \% \mathrm{Etc}\left(\mathrm{EC}_{\mathrm{iw}}=3,6 \mathrm{dSm}^{-1}\right)$ & $79.93 \mathrm{ab}$ & $74.17 \mathrm{ab}$ & $66.57 \mathrm{ab}$ & $2.84 \mathrm{~b}$ & $3718.32 \mathrm{~b}$ \\
$\left.75 \% \mathrm{Etc}_{(\mathrm{EC}}=3,6 \mathrm{dSm}^{-1}\right)$ & $78.39 \mathrm{ab}$ & $71.78 \mathrm{~b}$ & $60.76 \mathrm{c}$ & $2.76 \mathrm{~b}$ & $3317.63 \mathrm{~b}$ \\
$100 \% \mathrm{Etc}\left(\mathrm{EC}_{\mathrm{iw}}=3,6 \mathrm{dSm}^{-1}\right)$ & $75.66 \mathrm{~b}$ & $72.06 \mathrm{~b}$ & $61.43 \mathrm{bc}$ & $2.77 \mathrm{~b}$ & $3359.20 \mathrm{~b}$ \\
$125 \% \mathrm{Etc}\left(\mathrm{EC}_{\mathrm{iw}}=3,6 \mathrm{dSm}^{-1}\right)$ & $78.80 \mathrm{ab}$ & $65.91 \mathrm{c}$ & $61.74 \mathrm{bc}$ & $2.81 \mathrm{~b}$ & $3427.63 \mathrm{~b}$ \\
\hline $\mathrm{CV}(\%)$ & 10.61 & 12.28 & 12.57 & 11.97 & 18.64 \\
\hline
\end{tabular}

*Means followed by same lowercase letters in the columns, for irrigation depths, do not differ from each other by the Tukey's test at $5 \%$ of significance level. 
The analysis of the variables of growth is fundamental to properly manage the pineapple and to identify any problem that might occur during the crop development. Concerning this study, we could identify that the weather conditions had a great effect, as much as the salinity did, on decreasing the variables of growth. Wind gusts reached up to 85 $\mathrm{km} \mathrm{h}^{-1}$, maximum temperature, $40.3{ }^{\circ} \mathrm{C}$, reference evapotranspiration, $9 \mathrm{~mm} \mathrm{day}^{-1}$, and relative humidity reached values as low as $26.8 \%$ (Figure 1), which wound up breaking and drying out the leaves of the pineapple plants. As a consequence, the weather interfered in the vegetative and physiological characteristics, as well as in the yield. This demonstrates that these characteristics limited more the crop development, even more than the salinity of the irrigation water, as we did not find any differences between saline water and good quality water.

Yield and fruit quality of 'Pérola' pineapple plants were evaluated. Only the ratios of total soluble solid content and total titratable acidity (TSS/TTA) were influenced by the different irrigation depths with saline water (Table 2).

Table 2. Yield, total soluble solids (TSS), $\mathrm{pH}$, total titratable acidity (TTA), and TSS/TTA ratio of 'Pérola' pineapple fruits subjected to different irrigation depths with saline water.

\begin{tabular}{cccccc}
\hline Depths & $\begin{array}{c}\text { Yield } \\
\left(\mathrm{kg} \mathrm{ha}^{-1}\right)\end{array}$ & $\begin{array}{c}\text { TSS } \\
\left({ }^{\circ} \text { Brix }\right)\end{array}$ & pH & $\begin{array}{c}\text { TTA } \\
(\% \text { of citric acid })\end{array}$ & TSS/TTA \\
\hline $100 \%$ ETc $\left(\mathrm{EC}_{\mathrm{iw}}=0,75 \mathrm{dSm}^{-1}\right)$ & $14.475 .5 \mathrm{a}$ & $15.4 \mathrm{a}$ & $3.79 \mathrm{a}$ & $0.78 \mathrm{a}$ & $19.89 \mathrm{a}$ \\
$50 \% \mathrm{ETc}\left(\mathrm{EC}_{\mathrm{iw}}=3,6 \mathrm{dS} \mathrm{m}^{-1}\right)$ & $5.157 \mathrm{~b}$ & $12.2 \mathrm{ab}$ & $3.75 \mathrm{a}$ & $0.73 \mathrm{a}$ & $16.64 \mathrm{ab}$ \\
$75 \% \mathrm{ETc}\left(\mathrm{EC}_{\mathrm{iw}}=3,6 \mathrm{dS} \mathrm{m}^{-1}\right)$ & $5.947 .5 \mathrm{~b}$ & $12.7 \mathrm{ab}$ & $3.73 \mathrm{a}$ & $0.76 \mathrm{a}$ & $16.84 \mathrm{a}$ \\
$100 \% \mathrm{ETc}^{-1}\left(\mathrm{EC}_{\mathrm{iw}}=3,6 \mathrm{dS} \mathrm{m}^{-1}\right)$ & $6.916 .5 \mathrm{ab}$ & $14.2 \mathrm{ab}$ & $3.73 \mathrm{a}$ & $0.87 \mathrm{a}$ & $16.43 \mathrm{ab}$ \\
$125 \% \mathrm{ETc}^{-1}\left(\mathrm{EC}_{\mathrm{iw}}=3,6 \mathrm{dS} \mathrm{m}^{-1}\right)$ & $2.711 \mathrm{~b}$ & $10.6 \mathrm{~b}$ & $3.84 \mathrm{a}$ & $0.89 \mathrm{a}$ & $11.91 \mathrm{~b}$ \\
\hline $\mathrm{CV}(\%)$ & 50.87 & 13.11 & 2.32 & 11.79 & 12.35 \\
\hline
\end{tabular}

*Means followed by same letters, in the columns, do not differ from each other by Tukey's test at 5\% of significance level.

Pineapple plants watered with irrigation depth $100 \%$ of ETc with water of $0.75 \mathrm{dS} \mathrm{m}^{-1}$ in $\mathrm{EC}_{\mathrm{iw}}$ yielded $14.4 \mathrm{t} \mathrm{ha}^{-1}$, which did not statistically differ from the yield of plants watered with $100 \%$ of ETc with saline water of $3.6 \mathrm{dS} \mathrm{m}^{-1}$ in $\mathrm{EC}_{\mathrm{iw}}(6.91 \mathrm{t}$ $\mathrm{ha}^{-1}$ ), but it did differ from those irrigated with 50 , 75 , and $125 \%$ of ETc with water of $3.6 \mathrm{dS} \mathrm{m}^{-1}$ in $\mathrm{EC}_{\mathrm{iw}}$. The yields we recorded in our experiment are far below than the average yields in Bahia state and Brazil, 25,213 and 26,148 $\mathrm{kg} \mathrm{ha}^{-1}$, respectively (IBGE, 2015), and yields found in other studies on pineapples under semi-arid conditions (FRANCO et al., 2014; MAIA et al., 2016).

The reason for such low yields, which were far lower than those found by the cited authors and than the expected yield for 'Pérola' pineapple, might be the lack of uniformity of the seedlings used at the planting, leaf damage due to frequent gusts of wind. Moreover, we verified, by testing the uniformity of water application, that the application efficiency of the irrigation system had decreased over the course of the experiment, which ended up applying different amounts of water where it was supposed to be uniform. Because of the afore mentioned reasons, we verified that yields that varied from 23,798.46 to $7467.31 \mathrm{~kg} \mathrm{ha}^{-1}$, across blocks, with application of $100 \%$ of ETc with water of $0.75 \mathrm{dS} \mathrm{m}^{-1}$ in $\mathrm{EC}_{\mathrm{iw}}$. It is worth mentioning that the population of plants used was only 33,300 plants $\mathrm{ha}^{-1}$, whereas in pineapple commercial fields, or even in studies we cited on this paper, the population varied from 41,666 to 51,280 plants ha $^{-1}$, which also contributed to low yields per unit area in this study.

The values of soluble solids (SS) were similar for depths that corresponded to $100 \%$ of ETc with water of $0.75 \mathrm{dS} \mathrm{m}^{-1}$ in $\mathrm{EC}_{\mathrm{iw}}$ and for depths 50 , 75 , and $100 \%$ of ETc with water of $3.6 \mathrm{dS} \mathrm{m}$. The lowest value of SS (10.61 ${ }^{\circ}$ Brix) was observed when applying the highest amount of saline water (125\% of ETc with water of $3.6 \mathrm{dS} \mathrm{m}^{-1}$ in $\mathrm{EC}_{\mathrm{iw}}$ ). These results indicate that up to $100 \%$ of ETc with water of $3.6 \mathrm{dS} \mathrm{m}^{-1}$ in $\mathrm{EC}_{\mathrm{iw}}$, the salinity does not affect soluble solids contents in pineapple fruits.

The optimum values of soluble solids in 'Pérola' pineapples fall in the range of 13.2-14.3 ${ }^{\circ}$ Brix in fresh, high-quality fruits (CHITARRA; CHITARRA, 2005). Therefore, only when applying $100 \%$ of $\operatorname{ETc}\left(0.75\right.$ and $3.6 \mathrm{dS} \mathrm{m}^{-1}$ in $\left.\mathrm{EC}_{\mathrm{iw}}\right)$, the value of soluble solids remained within the established range; in fact, when using water with better quality $\left(0.75 \mathrm{dS} \mathrm{m}^{-1}\right.$ in $\left.\mathrm{EC}_{\mathrm{iw}}\right)$, the value of soluble solids ended up being above the range (15.45 ${ }^{\circ}$ Brix). According to the Pineapple Classification Guide (Normas de Classificação de Abacaxi - CHQ/CEAGESP), in general, to sell pineapples in Brazil, it is required the minimum 12 ${ }^{\circ}$ Brix; thus, only when applying $125 \%$ of ETc with water of $3.6 \mathrm{dS} \mathrm{m}^{-1}$ in $\mathrm{EC}_{\mathrm{iw}}$, the fruit would meet the standard for the Brazilian fruit market. 
Irrigation with saline...

Sugar content, expressed by the percentage of total soluble solids (TSS) or ${ }^{\circ}$ Brix, is a very important variable to determine the fruit quality. This variable is usually used as a maturity index for some fruits and indicates the amount of substances found dissolved in the juice; also, ${ }^{\circ}$ Brix increases as the sugars accumulate in the fruit (SOUZA et al., 2013; SILVA et al., 2011). Therefore, the values found in this study, for fruit quality, indicate potential for pineapple production, especially for fruits meant to be eaten fresh; although, further research must be done so as to increase yields of pineapple and to make viable the cultivation of pineapple in semi-arid regions.

In respect of $\mathrm{pH}$, there was no significant difference when applying the different depths. The values of $\mathrm{pH}$ varied from 3.73 to 3.8 . The titratable acidity responded in a similar way and the mean values varied from 0.73 to $0.89 \%$; thus, they are within the range of 0.75 to $1.15 \%$, set by Manica (2000). This variation of $\mathrm{pH}$, associated with the values of soluble solids and acidity, indicates that the harvest was performed at the right season as these variables are associated with the ripening of the fruits (Souza et al., 2013).

The water application of $100 \%$ of ETc with water of $0.75 \mathrm{dS} \mathrm{m}^{-1}$ in $\mathrm{EC}_{\mathrm{iw}}$ and $75 \%$ of ETc with water of $3.6 \mathrm{dS} \mathrm{m}^{-1}$ in $\mathrm{EC}_{\mathrm{iw}}$, provided the highest values of $\mathrm{SS} / \mathrm{TA}$ ratio $(19.89$ and 16.84 , respectively); though, they differed only from the depth $125 \%$ of ETc with water of $3.6 \mathrm{dS} \mathrm{m}^{-1}$ in $\mathrm{EC}_{\mathrm{iw}}$, in which the lowest mean value was of 11.91 .

As for fruit quality, the results indicate that the application of saline water can be used to grow pineapples under semi-arid conditions, provided that the yield is increased up to commercial standards. To do so, further studies should be done in semi-arid regions with the aim of establishing an adequate irrigation management with saline water.

Water-use efficiency (WUE) on 'Pérola' pineapple varied with the application of different irrigation depths. Applying 100\% of ETc with water of $0.75 \mathrm{dS} \mathrm{m}^{-1}$ in $\mathrm{EC}_{\mathrm{iw}}$, whose WUE was $3.65 \mathrm{~kg}$ $\mathrm{ha}^{-1} \mathrm{~mm}^{-1}$, was similar to depths of 50,75 , and $100 \%$ of ETc with water of $3.6 \mathrm{dS} \mathrm{m}^{-1}$ in $\mathrm{EC}_{\mathrm{iw}}$,
BRITO, C. F. B. et al.

which exhibited WUE of $2.09,1.82$, and $1.72 \mathrm{~kg}^{-1}$ ${ }^{1} \mathrm{~mm}^{-1}$, respectively. With only $0.53 \mathrm{~kg} \mathrm{ha}^{-1} \mathrm{~mm}^{-1}$, the irrigation depth of $125 \%$ of ETc with water of $3.6 \mathrm{dS} \mathrm{m}^{-1}$ exhibited the lowest WUE.

These values of WUE are considered low and this is because of the values of yield falling below the commercial crop yields in every treatment of our study. With pineapples irrigated by four different amounts of water $(50 \%, 75 \%, 100 \%$, and $125 \%$ of ETc), Souza et al. (2012) found WUE of $21.84 \mathrm{~kg} \mathrm{~m}^{-3}$ with $50 \%$ of ETc as irrigation depth and yield of $77,000 \mathrm{~kg} \mathrm{ha}^{-1}$. Therefore, it is inferred that higher values of WUE can be obtained by decreasing the amount of applied water or by increasing yield.

From a sustainability standpoint of water resources, the increment in yield would result in enabling growing pineapples in the semi-arid as it would also increase the WUE, which is currently one of the main limiting factors on agricultural production in the semi-arid region.

\section{CONCLUSIONS}

The irrigation depth $100 \%$ of ETc with waters of $0.75 \mathrm{dS}$ and $3.6 \mathrm{dS} \mathrm{m}^{-1}$ provided the best yields under the semi-arid conditions of this study.

The characteristics of chemical quality of 'Pérola' pineapple fruits are up to the commercial standards, except with water application of $125 \%$ of $\mathrm{ETc}$ with water of $3.6 \mathrm{dS} \mathrm{m}^{-1}$ in $\mathrm{EC}_{\mathrm{iw}}$.

\section{ACKNOWLEDGEMENTS}

We would like to thank the National Council for Scientific and Technological Development $(\mathrm{CNPq})$ for the financial support and for providing scholarships.

We also thank the Professional Master Program in Agricultural Production in the Semi-arid at the Federal Institute of Education, Science, and Technology of Bahia (IF Baiano), campus Guanambi, for supplying the equipment, personnel, and area to conduct the experiment.

RESUMO: Objetivou-se avaliar o uso de diferentes lâminas de irrigação com água salina nas características de crescimento, produtividade, eficiência de uso da água e qualidade do abacaxizeiro 'Perola' no semiárido baiano. $\mathrm{O}$ experimento foi conduzido em blocos casualizados com cinco tratamentos representados pelas lâminas de irrigação: $100 \%$ da evapotranspiração da cultura (ETc) com água de condutividade elétrica (CEa) de $0,75 \mathrm{dS} \mathrm{m}^{-1}$ e 50, 75, 100 e 125\% da ETc com aplicação de água de CEa de 3,6 $\mathrm{dS} \mathrm{m}^{-1}$. A cultura foi conduzida em condições de campo com a utilização do sistema de irrigação por gotejamento, com gotejadores autocompensantes de vazão nominal de $8 \mathrm{~L} \mathrm{~h}^{-1}$. Verificou-se que a lâmina de irrigação referente a $100 \%$ da ETc com água de $\mathrm{CEa}$ de 0,75 e 3,6 $\mathrm{dS} \mathrm{m}^{-1}$ proporciona as melhores produtividades nas condições do presente 
estudo e as características de qualidade química do fruto do abacaxi 'Pérola' estão dentro dos padrões de comercialização, exceto com aplicação de lâmina referente a $125 \%$ da ETc com água de CEa de 3,6 dS m ${ }^{-1}$.

PALAVRAS-CHAVE: Ananas comosus. Salinidade, Plantas CAM, Manejo da irrigação.

\section{REFERENCES}

ALVARES, C. A.; STAPE, J. L.; SENTELHAS, P. C.; GONÇALVES, J. L. M.; SPAROVEK, G. Köppen's climate classification map for Brazil. Meteorologische Zeitschrift, Stuttgart, v. 22, p. 711-728, 2013. http://dx.doi.org/10.1127/0941-2948/2013/0507

ARAGON, C.; CARVALHO, L.; GONZÁLEZ, J.; ESCALONA, M.; AMANCIO, S. The physiology of ex vitro pineapple (Ananas comosus (L.) Merr. Var MD-2) as CAM or C3 is regulated by the environmental conditions. Plant Cell Reports, v.31, p. 57-769, 2012. https://doi.org/10.1007/s00299-011-1195-7

ARAGÜÉSA, R.; MEDINA, E. T.; CLAVERÍA, I.; MARTÍNEZ-COBB, A.; FACI, J. Regulated deficit irrigation, soil salinization and soil sodification in a table grape vineyard drip-irrigated with moderately saline waters. Agricultural Water Management, Madri, v.134, p.84-93, 2014.

https://doi.org/10.1016/j.agwat.2013.11.019

AZEVEDO, P. V.; SOUZA, C. B. de.; SILVA, B. B.; SILVA, V. P.R. Water requirements of pineapple crop grown in a tropical environment, Brazil. Agricultural Water Management, Madri, v. 88, n. 1, p. 201-208, 2007. https://doi.org/10.1016/j.agwat.2006.10.021

BORLAND, A. M.; HARTWELL, J.; WESTON, D. J.; SCHLAUCH, K. A.; TSCHAPLINSKI, T. J.; TUSKAN, G. A.; YANG, X.; CUSHMAN J. C. Engineering crassulacean acid metabolism to improve wateruse efficiency. Trends in Plant Science, Xi'an, v. 19, n. 5, p. 327-338, 2014.

https://doi.org/10.1016/j.tplants.2014.01.00

CARDOSO, M. M.; PEGORARO, R. F.; MAIA, V. M.; KONDO, M. K.; FERNANDES, L. A. Crescimento do abacaxizeiro 'Vitória' irrigado sob diferentes densidades populacionais, fontes e doses de nitrogênio. Revista Brasileira de Fruticultura, Jaboticabal, v. 35, n. 3, p. 769-781, 2013. http://dx.doi.org/10.1590/S010029452013000300014

CARR, M. K. V. The water relations and irrigation requirements of pineapple (Ananas comosus var. comosus): a review. Experimental Agriculture, Cambridge, v. 48, n. 4, p. 488-501, 2012.

http://dx.doi.org/10.1017/S0014479712000385

CHITARRA, M. I. F.; CHITARRA, A.B. Qualidade pós-colheita de frutos e hortaliças: fisiologia e manuseio. Lavras: ESAL/FAEPE, 2005. p. 783.

COUTO, T. R.; SILVA, J. R.; MORAES C. R. O.; RIBEIRO, M. S.; NETTO, A. T.; CARVALHO, V. S.; CAMPOSTRINI, E. Photosynthetic metabolism and growth of pineapple (Ananas comosus L. Merr.) cultivated ex vitro. Theoretical and Experimental Plant Physiology, v. 28, n. 3, p. 333-339, 2016.

http://dx.doi.org/10.1007/s40626-016-0062-x

ELHAG, A. Z.; ELZAIN, H. Sodium chloride tolerance of pineapple (Ananas comosus 1. Mirrl.) In vitro. Journal of Applied Agricultural Research, Abuja, v. 4, n. 2, p. 105-110, 2012.

EMPRESA BRASILEIRA DE PESQUISA AGROPECUÁRIA- EMBRAPA. Manual de métodos de análise de solo ( $2^{\mathrm{a}}$ ed.). Rio de Janeiro, RJ: Centro Nacional de Pesquisa de Solos. 1997. 212 p. 
FRANCO, L. R. L.; MAIA, V. M.; LOPES, O. P.; FRANCO, W. T. N.; SANTOS, S. R. Crescimento, produção e qualidade do abacaxizeiro 'Pérola'sob diferentes lâminas de irrigação. Revista Caatinga, Mossoró, v. 27, n. 2, p. 132-140, 2014.

GUIMARÃES, M. J. M.; SIMÕES, W. L.; TABOSA, J. N.; SANTOS, J. E.; WILLADINO, L. Cultivation of forage sorghum varieties irrigated with saline effluent from fish-farming under semi-arid conditions. Revista Brasileira de Engenharia Agrícola e Ambiental, Campina Grande, v. 20, n. 3, p. 461-465, 2016. http://dx.doi.org/10.1590/1807-1929/agriambi.v20n5p461-46

HAMED, A. M.; ALI E. A. M. Effect of different sea water concentrations ongrowth parameters of pineapple (Ananas comosus) in vitro and in vivo. Journal of Applied Sciences Research, Islamabad, v. 3, n. 8, p. 713$722,2007$.

HANAFI, M. M.; SHADULLAHI, S. M.; NIAZUDDIN, M.; ABD AZIZ, Z.; MOHAMMUD, C. H. Potential use of sea water for pineapple production in BRIS soil. International Journal of Agricultural \& Biology, v. 12, n. 3, p. 396-400, 2010.

IBRAHIM, M. A. Effect of $\mathrm{NaCl}$ stress on pineapple plant (Ananas comosus Merr. (L.) cv. Del Monte) in vitro. International Journal of Farming and Allied Sciences, Peshawar, v. 9, n. 2, p. 206-210, 2013.

INSTITUTO BRASILEIRO DE GEOGRAFIA E ESTATÍSTICA-IBGE. Produção Agrícola Municipal. Sistema IBGE de Recuperação Automática-SIDRA. 2015. Disponível em: http://www.sidra.ibge.gov.br Acesso em: 05/04/2017

MAIA, V. M.; OLIVEIRA, F. S.; PEGORARO, R. F.; ASPIAZÚ, I.; PEREIRA, M. C. T. "Pérola" pineapple growth under semi-arid climate conditions. Acta Horticuture, Leuven, v.111, n. 1, p. 267-263, 2016. http://dx.doi.org/10.17660/ActaHortic.2016.1111.38

MANICA, I. Abacaxi: plantio ao mercado. Porto Alegre, Cinco Continentes, 2000, 122 p.

MELO, A. S.; AGUIAR NETTO, A. O.; NETO, J. D.; BRITO, M. E. B.;VIÉGAS, P. R. A.; MAGALHÃES, L. T. S.; FERNANDES, P. D. Desenvolvimento vegetativo, rendimento da fruta e otimização do abacaxizeiro cv. Pérola em diferentes níveis de irrigação. Ciência Rural, Santa Maria, v. 36, n. 1, p. 93-98, 2006. http://dx.doi.org/10.1590/S0103-84782006000100014

MELO, Y. L.; DANTAS, C. V. S.; LIMA-MELO, Y.; MAIA, J. M.; MACÊDO, C. E. C. de. Changes in osmotic and ionic indicators in Ananas comosus (L.) cv. MD Gold pre-treated with phytohormones and submitted to saline medium. Revista Brasileira de Fruticultura, Jaboticabal, v. 39, n. 2, p. 01-14, 2017. http://dx.doi.org/10.1590/0100-29452017155

MOTA, M. F. C.; PEGORARO, R. F.; BATISTA, P. S. C.; PINTO, V. O.; MAIA, V. M.; SILVA, D. F. Macronutrients accumulation and growth of pineapple cultivars submitted to aluminum stress. Revista Brasileira de Engenharia Agrícola e Ambiental, Campina Grande, v. 20, n. 11, p. 978-983, 2016. http://dx.doi.org/10.1590/1807-1929/agriambi.v20n11p978-983

PEGORARO, R. F.; SOUZA, B. A. M.; MAIA, V. M.; AMARAL, U.; PEREIRA, M. C. T. Growth and production of irrigated Vitória pineapple grown in semi-arid conditions. Revista Brasileira de Fruticultura, Jaboticabal, v. 36, n. 3, p. 693- 703, 2014. http://dx.doi.org/10.1590/0100-2945-265/13

REINHARDT, D. H.; SOUZA, L. F. S.; CABRAL, J. R. S. Abacaxi. Produção: aspectos técnicos. Cruz das Almas, Embrapa Mandioca e Fruticultura, 2000. 244p.

RICHARDS, L. A. (Ed.). Diagnosis and improvement of saline and alkali soils. Washington: USDA, 1954. 160p. il. (USDA. Agriculture Handbook, 060). 
RODRIGUES, A. A.; MENDONÇA, R. M. N.; SILVA, A. P. DA.; SILVA, S. V.; PEREIRA, W. E. Desenvolvimento vegetativo de abacaxizeiros 'Pérola' e 'SmoothCayenne' no estado da Paraíba. Revista Brasileira de Fruticultura, Jaboticabal, v. 32, n. 1, p. 126-134, 2010. http://dx.doi.org/10.1590/S010029452010005000031

SANTANA, M. J.; SOUZA, O. P.; CAMARGOS, A. E. V.; ANDRADE, J. P. R. Coeficientes de cultura do abacaxizeiro nas condições edafoclimáticas de Uberaba, MG. Revista Brasileira de Engenharia Agrícola e Ambiental, Campina Grande, v. 17, n. 6, p. 602-607, 2013. http://dx.doi.org/10.1590/S141543662013000600005

SANTOS, M. R.; MARTINEZ, M. A.; DONATO, S. L. R.; COELHO, E. F. Fruit yield and root system distribution of 'Tommy Atkins' mango under different irrigation regimes. Revista Brasileira de Engenharia Agrícola e Ambiental, Campina Grande, v.18, p.362-369, 2014. http://dx.doi.org/10.1590/S141543662014000400002

SANTOS, M. R.; NEVES, B. R.; SILVA, B. L.; DONATO, S. L. R. Yield, water use efficiency and physiological characteristic of 'Tommy Atkins' mango under partial rootzone drying irrigation system. Journal of Water Resource and Protection, Madri, v.7, p.1029-1037, 2015.

http://dx.doi.org/10.4236/jwarp.2015.713084

SANTOS, M. P.; MAIA, V. M.; OLIVEIRA, F. S.; PEGORARO, R. F.; SANTOS, S. R.; ASPIAZÚ, I. Estimation of total leaf area and D leaf area of pineapple from biometric characteristics. Revista Brasileira de Fruticultura, Jaboticabal, v. 40, n. 6, p. 01-04, 2018.http://dx.doi.org/10.1590/0100-29452018556

SILVA, D. M.; SANTOS, K. T.; DUARTE, M. M. Eficiência fotoquímica em folhas do mamoeiro (carica papaya L.) cv. Golden durante o estádio reprodutivo e caracterização da ontogenia dos frutos. Revista Brasileira de Fruticultura, Jaboticabal, v. 33, n. 4, p. 1066-1073, 2011. http://dx.doi.org/10.1590/S010029452011000400004

SOUZA, O. P.; ZANINI, J. R.; TORRES, J. R. L.; BARRETO, A. B.; SOUZA, E. L. C. Produção e qualidade física dos frutos do abacaxi sob diferentes lâminas e frequências de irrigação. Irriga, Botucatu, v. 17, n. 4, p. 534 - 546, 2012. http://dx.doi.org/10.15809/irriga.2012v17n4p534

SOUZA, O. P.; ZANINI, J. R.; TORRES, J. R. L.; BARRETO, A. B.; SOUZA, E. L. C. Rendimento do suco e qualidade química do abacaxi sob lâminas e frequências de irrigação. Bioscience Journal, Uberlândia, v. 29, n. 6, p. 1971-1980, 2013.

TEDESCO, M. J.; GIANELLO, C.; BISSANI, C. A.; BOHNEN, H.; VOLKWEISS, S. J. Análise de solos, plantas e outros materiais. Porto Alegre, RS: Universidade Federal do Rio Grande do Sul. 1995. 174 p.

ZHANG, J.; LIU, J.; MING, R. Genomic analyses of the CAM plant pineapple. Journal of Experimental Botany, Oxford, v. 65, n. 13, p. 01-10, 2014. https://doi.org/10.1093/jxb/eru101 